\title{
Factors Responsible for Asthma and Rhinitis among Kuwaiti Schoolchildren
}

\author{
A.T. Abal $^{\text {a }}$ A. Ayed ${ }^{\text {b P.C.M.G. Nair }}{ }^{c}$ M. Mosawic ${ }^{c}$ N. Behbehanic \\ Departments of a Medicine and ${ }^{b}$ Surgery, Faculty of Medicine, Kuwait University, and ${ }^{c}$ Ministry of Health, Kuwait
}

\author{
Key Words \\ Asthma - Rhinitis - Dermatophagoides • House dust mite • \\ Der $\mathrm{p} 1$ levels
}

\begin{abstract}
Objective: The aim of this study was to assess the prevalence of asthma among schoolchildren and to determine the level house dust mites in Kuwaiti homes and its role in asthma and rhinitis. Subjects and Method: The International Study of Asthma and Allergy in Children questionnaire was distributed to schoolchildren in the age group of 5-7 years, after random sampling from all the five governorates of Kuwait. The questionnaires were completed and initiated by parents with the help of the investigator and parents. House dust was collected from the bedroom floor of 549 houses in the same geographical areas where the schoolchildren were sampled, extracted and assayed for mite Der $p 1$ by ELISA method. Results: The estimated prevalence of asthma was $22.4 \%$ and that of rhinitis was $23 \%$. House dust collected from the bedroom floor was found to contain low levels of Der $p$ 1. There was no significant difference $(p=0.969)$ in the level of Der $p 1$ between areas in Kuwait. The highest levels of Der $\mathrm{p} 1 \mathrm{ranged}$ from 0.02 to $0.10 \mathrm{mg} / \mathrm{g}$ in $3.5 \%$ of the total samples examined. Conclusions: There is a high prevalence of asthma and rhinitis among the schoolchildren in Kuwait. However, the level of dust mitogens investigated in this study was below the level of concern, thus undermining their role in increasing asthma cases in Kuwait. Therefore,
\end{abstract}

further studies are needed to understand the role of other mite allergens and other factors that contribute to the increased prevalence of allergic diseases in Kuwaiti children.

Copyright $\odot 2010$ S. Karger AG, Basel

\section{Introduction}

Studies conducted in Kuwait have revealed a high prevalence of allergic diseases, especially asthma in children, compared to other countries [1]. Atmospheric pollution due to the prolonged burning of more than 700 oil wells torched during the Gulf War has been considered as one of the reasons for the increase in allergic and respiratory diseases [2]. An analysis of patients admitted to hospital with asthma, as per International Classification of Diseases, before and after the Gulf War (1987-1989 and 19921994) showed no statistically significant differences in either hospital admissions or death rates attributable to asthma. However, the number of hospital admissions in young adult Kuwaiti nationals increased in the post-Gulf War period [3]. This prompted us to investigate factors contributing to airway diseases in Kuwait. Asthma and rhinitis are environmental diseases that are caused in most patients by the continual inhalation of allergens of indoor and outdoor origin and the exact sensitivities to these vary among people. It remains to be established which factors contribute to the occurrence of asthma in allergic individuals [4]. Indoor air exposures are more

Dr. Adnan T. Abal, Associate Professo Faculty of Medicine, Kuwait University PO Box 6674

Salmiya 22077 (Kuwait)

Tel. +965 9792 3803, Fax +965 2484 5048, E-Mail adnan_abal@ hotmail.com 
Table 1. Guidelines for the Dermatophagoides mite allergen levels in house dust

\begin{tabular}{lll}
\hline Mites & Comment & Rank \\
\hline$<2 \mu$ g Der p 1/g dust & $\begin{array}{l}\text { not sufficient to cause } \\
\text { allergic symptoms }\end{array}$ & low \\
\hline $2-10 \mu$ g Der p 1/g dust & $\begin{array}{l}\text { risk for sensitization and } \\
\text { bronchial hyperactivity }\end{array}$ & significant \\
\hline$>10 \mu$ g Der p 1/g dust & $\begin{array}{l}\text { risk for acute asthmatic } \\
\text { attack }\end{array}$ & high \\
& & \\
& &
\end{tabular}

strongly linked to the increase in asthma prevalence [5]. Exposure to house dust mites can cause symptoms ranging from atopic dermatitis to bronchial asthma in genetically susceptible individuals and may also exacerbate existing asthma $[6,7]$. Recent studies did not show major benefits of successful reduction of mite allergens in causing a decrease in asthma or atopic dermatitis symptoms $[8$, 9], but well-controlled studies have provided evidence of a beneficial effect $[10,11]$. Therefore, we decided to study the prevalence of asthma/rhinitis and the level of house dust mite in Kuwait and its role in asthma and rhinitis.

\section{Materials and Methods}

In the present study, dust samples from the bedroom floors of 549 houses in five governorates in Kuwait were collected between July and August 1999 and examined for the dust mite Dermatophagoides pteronyssinus (Der p 1) in order to determine its role in the precipitation of asthma and rhinitis.

\section{Questionnaire}

The standard questionnaire of the International Study of Asthma and Allergy in Children was used and distributed to 2,500 schoolchildren on the basis of random sampling from the five governorates. The targeted age groups were the schoolchildren of 5-7 years. The Arabic version of the English-language questionnaire was distributed, and completed by parents with the assistance from the respiratory therapist. A total of 2,117 questionnaires were properly completed; of these, 1,163 were male and 954 female children. The children were born immediately after the first Gulf War and 2 years later.

The completed questionnaires were analyzed using SPSS version 8 and statistical significance was set at $\mathrm{p}$ value $<0.5$.

\section{Collection of House Dust Samples}

Five hundred and forty-nine houses from the five governorates of Kuwait were selected for house dust collection of which 111 were from the capital area, 112 from Hawalli, 119 from Farwaniya, 115 from Ahmadi and 92 from Jahra area.
House dust samples were collected using a Hoover Sprint 100 vacuum cleaner (model SI 211, The Hoover Co., Canton, Ohio, USA). The vacuum cleaner was adapted to collect the dust samples onto an 8-inch squared sheet of bed linen. A dust trap located behind the cleaner attachment supported the sheet. The sample was collected from an area of $1 \mathrm{~m}^{2}$ for $2 \mathrm{~min}$. The sheet and dust sample were stored at $4^{\circ} \mathrm{C}$ in mini grip lock bags.

\section{Extraction}

The dust was sieved through a No. 45 mesh screen, $355 \mu \mathrm{m}$ in diameter (VWR No. 57332146) to remove large particles and fibers. Fine dust particles were weighed $(100 \pm 5 \mathrm{mg})$ and put into a $75 \times 12 \mathrm{~mm}$ plastic test tube (Sarstedt Co., Nümbrecht, Germany) and $2.0 \mathrm{ml} \mathrm{PBS-T} \mathrm{(0.05 \%} \mathrm{Tween} 20$ in phosphate-buffered saline, $\mathrm{pH}$ 7.4) was added. The dust was suspended using a vortex mixer (Vortex-Genie, Fisher Scientific, Bohemia, N.Y., USA) and mixed end over end on an orbital rotator (Multi-Purpose Rotator, Model 151, Scientific Laboratories Inc., Bohemia, N.Y., USA) for $2 \mathrm{~h}$ at room temperature or at $4^{\circ} \mathrm{C}$ overnight. The suspension was centrifuged for $20 \mathrm{~min}$ at $2,500 \mathrm{rpm}$ at $4^{\circ} \mathrm{C}$. The supernatant (approximately $1.5 \mathrm{ml}$ ) was removed with a Pasture pipette and stored at $-20^{\circ} \mathrm{C}$ for the measurement of antigen and the pellet was discarded.

\section{ELISA Protocol for Mite Der $p 1$ Determination}

The method of Chapman et al. [12] was used for determination of Der $\mathrm{p} 1$ as given below. Anti-Der $\mathrm{p} 1 \mathrm{mAb} 5 \mathrm{H} 8$, HPLC purified procured as a stock solution at $2 \mathrm{mg} / \mathrm{ml}$ in PBS and anti-Der $\mathrm{f} 1$ $\mathrm{mAb} 6 \mathrm{~A} 8$ freeze-dried ammonium sulfate fraction of ascites was suspended in $1 \mathrm{ml} \mathrm{PBS}$ at $10 \mathrm{mg} / \mathrm{ml}$ concentration. Polystyrene microtiter wells (Immulon II) were coated with either $200 \mathrm{ng} /$ well $5 \mathrm{H} 8$ or $1 \mathrm{mg} /$ well of $6 \mathrm{~A} 8$ (i.e. $0.1 \mathrm{ml} \mathrm{1/1,000} \mathrm{dilution} \mathrm{of} \mathrm{mAb}$ ) in $50 \mathrm{mM}$ carbonate buffer, $\mathrm{pH} 9.6$, overnight at $40^{\circ} \mathrm{C}$. The wells were washed twice with PBS-T (PBS with $0.05 \%$ Tween 20 , pH 7.4) and incubated for $1 \mathrm{~h}$ with $0.1 \mathrm{ml} 1 \%$ bovine serum albumin PBS-T then washed twice with PBS-T and dried; $0.1 \mathrm{ml}$ of diluted allergen samples were added and incubated for $1 \mathrm{~h}$. House dust samples were routinely diluted twofold from $1 / 10$ to $1 / 80$. A control curve was made using doubling dilutions of a reference Der $\mathrm{p} 1$, dilutions being from 250 to $0.5 \mathrm{ng} / \mathrm{ml}$ Der $\mathrm{p} 1$. The wells were washed 5 times with PBS-T and incubated for $1 \mathrm{~h}$ with $0.1 \mathrm{ml}$ 1/1,000 dilution of biotinylated 4C1 (equivalent to $16 \mathrm{ng} 4 \mathrm{C} 1$ antibody). This $\mathrm{mAb}$ was used as a second antibody for Der $\mathrm{p} 1$. The wells were washed 5 times and incubated for $30 \mathrm{~min}$ with $0.1 \mathrm{ml}$ $1 / 1,000$ dilution of streptavidin-peroxidase (Sigma S5512, $0.25 \mathrm{mg}$ reconstituted in $1 \mathrm{ml}$ distilled water). Streptavidin was diluted in $1 \%$ bovine serum albumin PBS-T. The wells were washed 5 times and developed by adding $0.1 \mathrm{ml} 1-\mathrm{mm}$ ABTS in $70 \mathrm{~mm}$ citrate phosphate buffer, $\mathrm{pH} 4.2$. The plate was read when the absorbance at $405 \mathrm{~nm}$ reached $2.0-2.4$ or the reaction stopped by adding 0.1 $\mathrm{ml} 2$-mM sodium azide. The absorbance readings were directly proportional to the quantity of Der $\mathrm{p} 1$ bound and the values were interpolated from the respective control curves.

The values of Der $\mathrm{p} 1$ were calculated as micrograms per gram of dust and ranked on the basis of suggested guidelines for the categorization of the Dermatophagoides mite allergen levels in house dust mites (table 1). 
Table 2. Prevalence of wheezing/rhinitis symptoms of different frequency and severity

\begin{tabular}{|c|c|c|c|c|c|c|}
\hline & \multicolumn{2}{|l|}{ Boys } & \multicolumn{2}{|c|}{ Girls } & \multicolumn{2}{|l|}{ Total } \\
\hline & $\mathrm{n}$ & $\%$ & $\mathrm{n}$ & $\%$ & $\mathrm{n}$ & $\%$ \\
\hline Sex & 1,163 & 54.9 & 954 & 45.1 & 2,117 & 100 \\
\hline Wheeze ever* & 314 & 27.4 & 157 & 16.5 & 471 & 22.4 \\
\hline Wheeze in the past 12 months* & 178 & 15.5 & 83 & 8.7 & 261 & 12.4 \\
\hline 1-3 episodes & 97 & 8.3 & 80 & 8.4 & 177 & 8.4 \\
\hline 4-12 episodes & 25 & 2.1 & 17 & 1.7 & 42 & 2 \\
\hline$>12$ episodes & 12 & 1.1 & 11 & 1.1 & 23 & 1.1 \\
\hline \multicolumn{7}{|l|}{ Nocturnal wheeze in the past } \\
\hline$<1$ night per week & 60 & 5.1 & 43 & 4.5 & 103 & 4.9 \\
\hline$>1$ night per week & 53 & 4.5 & 41 & 4.2 & 94 & 4.4 \\
\hline Severe wheeze in the last year & 45 & 3.8 & 38 & 3.9 & 83 & 3.9 \\
\hline Asthma diagnosis by physician* & 229 & 20 & 121 & 12.7 & 350 & 16.5 \\
\hline Exercise-induced wheeze & 122 & 10.7 & 62 & 6.5 & 184 & 8.8 \\
\hline Nocturnal cough in the last year* & 351 & 3 & 242 & 2.5 & 593 & 2.8 \\
\hline Sneezing and stuffy nose ever & 279 & 24.4 & 206 & 21.6 & 485 & 23 \\
\hline Allergic symptoms in last 12 months & 165 & 14.1 & 150 & 15.1 & 315 & 15 \\
\hline Physician's diagnosis of allergic rhinitis & 138 & 12.1 & 92 & 9.7 & 230 & 11 \\
\hline
\end{tabular}

\section{Results}

Of the 2,117 schoolchildren analyzed in this study, $471(22.4 \%)$ reported wheezing and 261 (12.4\%) rhinitis in the last 12 months (table 2). Three hundred and fifty (16.5\%, 229 male and 121 female) reported to have been diagnosed with asthma by the attending physician; 485 (23\%) reported sneezing, 315 (15\%) sneezing and itching indicative of allergic rhinitis, and 230 (11\%) reported a physician's diagnosis of allergic rhinitis. Reported prevalence of asthma was $22.4 \%$ and that of allergic rhinitis was $23 \%$.

The frequency of Der p 1 level in Kuwaiti house dust is given in table 3. Based on the classification in table 1, the frequency of Der $p 1$ in the 549 houses examined was as follows: zero to not significant: 515 (93.6\%); extremely low (i.e. $<0.02 \mu \mathrm{g} / \mathrm{g}): 15$ (2.7\%); slightly more $(0.02-$ $0.10 \mu \mathrm{g} / \mathrm{g}$ ) but not sufficient to cause any allergic symptoms: 19 (3.5\%) (table 3). None of the dust samples examined contained significant or high levels of Der $\mathrm{p} 1$ with a risk for sensitization and bronchial hyperactivity. The distribution in various areas of Kuwait also showed no significant difference $(\mathrm{p}$ value $=0.969)$ in the pattern of Der p 1 between areas in Kuwait (table 3). However, the highest levels were detected in the Capital area and Hawalli followed by Ahmadi, Jahra and Farwaniya governorates.

Factors Responsible for Asthma/Rhinitis among Kuwaiti Children
Table 3. Frequency of Der p1 level in house dust from five governorates of Kuwait

\begin{tabular}{lllll}
\hline \multirow{2}{*}{$\begin{array}{l}\text { Area } \\
\text { governorate }\end{array}$} & \multicolumn{2}{l}{ Der p1 levels } & \multirow{2}{*}{ Total } \\
\cline { 2 - 4 } & 0 & $<0.2$ & $0.2-1.0$ & \\
\hline Capital & $102(19.8)$ & $4(26.7)$ & $5(26.3)$ & $111(20.2)$ \\
Hawalli & $104(20.2)$ & $3(20.0)$ & $5(26.3)$ & $112(20.4)$ \\
Farwaniya & $114(22.1)$ & $3(20.0)$ & $2(10.5)$ & $119(21.7)$ \\
Ahmadi & $108(21.0)$ & $3(20.0)$ & $4(21.1)$ & $115(20.9)$ \\
Jahra & $87(16.9)$ & $2(13.3)$ & $3(15.8)$ & $92(16.8)$ \\
\hline Total & 515 & 15 & 19 & 549 \\
\hline
\end{tabular}

Figures in parentheses indicate percentages. $\mathrm{p}=0.969$.

\section{Discussion}

The role of indoor aeroallergens is increasingly evidenced worldwide in the development of asthma, and among indoor allergens house dust mites are the most common source [13-16]. The prevalence of asthma (22\%) and that of allergic rhinitis (23\%) were higher than those of other studies from Italy, Switzerland (24.6 and 12\%, respectively), and Hong Kong (7\%) [17], but lower than that of the United Kingdom (15.6\%) [18]. Equally important, the prevalence of asthma in Kuwait was higher than

Med Princ Pract 2010;19:295-298 
that reported from UAE (6-7\%) and Saudi Arabia (10.3\%) [19].

Although the present study was conducted on bedroom dust, apparently the most important room in the house, only 2.7 and $3.5 \%$ of the houses had extremely low $(<0.02 \mu \mathrm{g} / \mathrm{g})$ and slightly higher $(0.02-0.10 \mu \mathrm{g} / \mathrm{g})$ levels of Der $\mathrm{p}$ 1, suggesting that dust mite allergen levels were below the level of concern that could cause any allergic symptoms, i.e. risk for sensitization and bronchial hyperactivity. The distribution pattern of Der $\mathrm{p} 1$ also showed no significant difference ( $\mathrm{p}$ value $=0.969)$ between different areas in Kuwait (table 3). The main limitations of this study were the lack of objective measurement of lung function and allergic phenotypes like food allergy and atopic dermatitis.

\section{Conclusion}

There is a high prevalence of asthma and rhinitis among schoolchildren in Kuwait. However, the level of house dust mite allergen was below the level of concern, thus undermining its role in increasing asthma cases in Kuwait. Further studies of the role of other mite allergens and other factors that contribute to the high prevalence of allergic diseases in Kuwaiti children are needed.

\section{Acknowledgments}

We would like to thank R. Maylain and R. Roy for their technical assistance. This paper is supported by a grant from Environment Public Authority, grant No. HOO6FA.

\section{References}

$>1$ Behbehani NA, Abul A, Syabbalo NC, Azeem AA, Shareef E, Al-Momens J: Prevalence of asthma, allergic rhinitis, and eczema in 13to 14-year-old children in Kuwait: an ISAAC study. Ann Allergy Asthma Immunol 2000; 85:58-63.

$>2$ Cowan DN, Lange JL, Heller J, Kirkpatrick J, DeBakey S: A case-control study of asthma among US-Army Gulf war veterans and modeled exposure to oil well fire smoke. Mil Med 2002;167:777-782.

3 Abul A, Nair MGPC, Behbehani NA, Sharma PN: Hospital admission and death rates from asthma in Kuwait during pre- and postGulf war periods. Ann Allergy Asthma Immunol 2001;86:465-468.

4 Rosenstreich DL, Moday HJ, Hudes G: Asthma and the environment. J Asthma 2003; 40(suppl):23-29.

$\checkmark 5$ Hijazi Z, Ezeamuzie CI, Khan M, Dowaisan AR: Characteristics of asthmatic children in Kuwait. J Asthma 2002;39:603-660.

-6 Brown A, Farmer K, MacDonald L, Kalsheker N, Pritchard D, Haslett C, Lamb J, Sallenave JM: House dust mite Der p 1 downregulates defenses of the lung by inactivating elastase inhibitors. Am J Respir Cell Mol Biol 2003;29:381-389.

$>7$ Etzel RA: How environmental exposures influence the development and exacerbation of asthma. Pediatrics 2003;112:233-239.
$>8$ Oosting AJ, de Bruin-Weller MS, Terreehorst I, Tempel, Pavlica Z, Aalberse RC, et al: Effect of mattress encasings on atopic dermatitis outcome measures in a double-blind, placebo-controlled study: the Dutch Mite Avoidance Study. J Allergy Clin Immunol 2002;110:500-506.

9 Rijssenheck-Nouwens LHM, Oosting AJ, de Bruin-Weller MS, Bregman I, de Monchy JGR, Postma DS: Clinical evaluation of the effects of anti allergic mattress covers in patients with moderate to severe asthma and house dust mite allergy: a randomized double blind placebo controlled study. Thorax 2002;57:784-790.

10 Platts-MillsTAE, Vaughan JW, Carter MC, Wood Folk JA: The role of interventions in established allergy: avoidance of indoor allergens in the treatment of chronic allergic diseases. J Allergy Clin Immunol 2000;106: 787-804.

11 Arshad SH, Bojarskas J, Tsitoura S, Mathew S, Mealy B, Dean T, KarmousI J, Frischer T, Kuehr J, Forster J: The SPACE study group: prevention of sensitization to house dust mite by allergen avoidance in school age children: a randomized controlled study. Clin Exp Allergy 2002;32:843-849.

12 Chapman MD, Heymann PW, Wilkins SR, Brown MJ, Plaus-Mills TAE: Monoclonal immunoassays for major dust mites (Dermatophagoides) allergens, Der $p 1$ and $\operatorname{Der} f 1$, and quantitative analysis of the allergen content of mite and house dust extracts. J Allergy Clin Immunol 1987;80:184-194.
13 Lai CL, Shyur SD, Wu CY, Chang CL, Chu SH: Specific IgE to 5 different major house dust mites among asthmatic children. Acta Paediatr Taiwan 2002;43:265-270.

14 Arshad SH: Indoor allergen exposures in the development of allergy and asthma. Curr Allergy Asthma Rep 2003;3:115-120.

15 Callahan KA, Eggleston PA, Rand CS, Kanchanaraksa S, Swartz LJ, Wood RA: Knowledge and practice of dust mite control by speciality care. Ann Allergy Asthma Immunol 2003;90:302-307.

16 Robertson CF, Dalton MF, Peat JK, Haby MM, Bauman A, Kennedy JD, Landan LI: Asthma and other atopic diseases in Australian children, Australian arm of the international study of asthma and allergy in childhood. Med J Aust 1998;168:434-438.

17 Leung R, Bishop J, Robertson CF: Prevalence of asthma and wheeze in Hong Kong school children: an international comparative study. Eur Respir J 1994:2046-2049.

18 Heijne den Bak J: Prevalence and management of asthma in children under 16 in one practice. BMJ 1986;292:175-176.

19 Bener A, Abdulrazzaq YM, Debuse P, Abdin $\mathrm{AH}$ : Asthma and wheezing as the cause of school absence. J Asthma 1994;31:93-98. 